\title{
СРАВНИТЕАЬНАЯ КОНФАИКТОАОГИЯ
}

\author{
Гиакагмини $\Phi$.
}

\section{ОСОБЕННОСТИ СОЦИААЬНОЙ И ПОАИТИЧЕСКОЙ КОММУНИКАЦИИ В ПРИГРАНИЧНЫХ РАЙОНАХ МАТИНСКОЙ АМЕРИКИ НА ПРИМЕРЕ БРАЗИАИИ, БОАИВИИ И ПАРАГВАЯ}

\begin{abstract}
Аннотация. Статья посвящен а сравнительному исследованию социальной и политической коммуникации в приграничных районах \атинской Америки на примере Бразилии, Боливии и Парагвал. Опираясь на принципы государственного суверенитета и котроля над территорией страны, центральные правительства всегда стремились к ограничению контактов и потоков в приграничных районах. Несмотря на это, границы представляют собой места коммуникачии между людьми разных культур, языков, наций и мировоззрения. Жители этих районов зависят от взаимноотношений с соседними странами, причем стараются обойти ограничения, введенные государствами без учета их интересов. Методологической основой исследования является системный, структурно-функциональный и сравнительно-политический подход, метод анализа, синтеза, наблюдения, моделирования, экспертных оченок, методы полевых исследований. В случае Аатинской Америки данное противостояние между государством и границей усублялось тем, что политические и экономические центры страны исторически располагались далеко от грании: это было противостояние «центра» и «периферий». Более того, начиональные элиты по-прежнему сосредоточивали все свое внимание на отночениях с европейскими странами и США за счет ослаблевания отношений с соседними странами. В значительной степени национальные элиты даже являлись конкурентными, поскольку их экономики зависели от экспорта сырья в мировые экономические центры. Такая отдаленность преплтствовала контролю со стороны государств за приграничными территориями и способствовала появлению так называемых «городов-близнецов», в которых два города разделяется лишь границей, чаще всего совпадающей с улииой или рекой. Недостатки инфраструктуры, связывающей «иентр» и «периферию», вынудили насемение приграничных зон развивать собственные каналы коммуникачии и взаимноотночений, особенно в сфере экономики.
\end{abstract}


Ключевые слова: Конфиктология, внешняя политика, Бразилия, Боливия, Парагвай, Аатинская Америка, приграничные районы, социальная коммуникация, политическая коммуникация, сотрудничество.

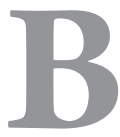

настоящее время прогрессивные правительства начали удемять внимание отношениям внутри континента и поощрять проекты интеграции межАу странами Аатинской Америки. При этом границы теперь явмяются не «периферией», а «центром» Аружбы народов. С целью укучшить отношения межАу странами весьма значимо рассматривать отношения на границах, так как в этих районах они Аавно укрепимись. Поэтомуавтором были провеАены исследования по социальным и политическим коммуникациям на границе Бразилии с Боливией и Парагваем. Основными методами исследования быми полевое наблюдение и интервьюирование местного населения, политических акторов и экспертов.

Социально-экономическая Аиспропорция межАу странами сильно влияет на коммуникацию и отношения межАу приграничными городами. Аанная обстановка порождала слеАующие явления:

- Посещение бразильских школ и помиклиник населением сосеАних стран с приграничных территорий, поскольку в Боливии и Парагвае инфраструктура относительно маморазвита и госучрежАения получают меньше ресурсов.

- Боливийцы и парагвайцы стараются, чтобы их дети рожАались на бразилськой стороне, так как, имея бразильское гражАанство, у них есть возможность получать государственные субсидии и социальные выплаты для малоимущих.

- Развитие торговли на стороне Парагвая и Боливии, с учетом того, что курс бразильского реала выше, чем курс валюты сосеАних стран, а налоги более высокие. В сложившейся ситуации бразимьцам выгоАно ходить за покупками в сосеАние города. Тем не менее, это вызывает конфликты в отношениях межАу торговцами обеих стран, так как условия конкуренции не равны.

- Поскольку боливийская и парагвайская сторона относительно менее развита, существуют преАрассуАки против насемения этих стран. Иногда это порождает забавные курьезы: извествен случай, когАа болийвский школьник жаловался бразимьскому преподавателю на то, что одноклассники назвали его «болийвицем».

- Болийвицы и парагвайцы часто смотрят бразимьские темеканалы, особенно сериалы, спортивные телепередачи и новости, в отличие от бразильцев, которые реАко смотрят боливийские и парагвайские телеканалы.

В приграничных городах мало бразимьцев говорят на испанском (хотя понимают), но большинство боливийцев и парагвайцев говорят по-португаньски. Это вызвано всеми вышеперечисленными факторами: зависимостью жителей приграничных городов сосеАних стран от бразильских государственных услуг, более качественным приемом сигнама бразимьского телевещания, чем парагвайского и боливийского, в приграничных зонах, наАичием преАрассуАков.

Криминальные группировки пользуются принципом суверенитета и недостаточной интеграцией и коммуникацией межАу государствами, особенно тем, что правоохранительные органы приграничных стран не могут пересекать границу. Помимо контрабанды, Аанная ситуация усуглубцяется тем, что Парагвай и Боливия являются соответственно вторым в мире самым большим поизводителем марихуаны и третьим самым большим производитемем кокаина.

В этих районах существует ряА неформальных законов с целью соответствия потребностям общества, обеспечения правопорялка, снижения уровня преступности и, в общем, избежания проблем, порожАающих принципом суверенитета. Хотя полицейские формально не могут пересекать границу, в чрезвычайных случаях они ее пересекают по соглашению с местными полицейскими. Тем не менее, неформальные правика и соглашения явцяются нестабимьными: бразимьские полицейские неоднократно были задержаны в Парагвае и обвинены национацьными СМИ в нарушении суверенитета страны. 
В сфере политики социальные и семейнные межАународные связи играют важную роль в приграничных отношениях. Местное самоуправление Бразимии провозгласимо официальный празАник в Аень независимость Боливии. То же само сАелали боливийские власти. Школы и вооруженные симы провоАят совместные парады. Губернатор Аепартамента в Парагвае утверАил, что его отношения с мэром бразимьского города бциже, чем с мэром парагвайского города. Местные городские Аепутаты создали PARLIM - межАународный муниципацьный парламент, чтобы совместно обсужАать проблемы, касающиеся обеих сторон границ.

В заключение, слеАует отметить неоАнозначность сущности этих районов: граница это территория, гАе Аве страны притягиваются и оАновременно отталкиваются Аруг от Аруга.

\section{БИБАИОГРАФИЯ}

1. MARTIN, André. Fronteiras e Nações. São Paulo: Contexto, 1992.

2. NUNES, Marcelino. PARLIM - Parlamento Internacional Municipal, Um Projeto de Integração. Dourados: Editor Nicanor Coelho, 2006.

3. RAFFESTIN, Claude. Por uma geografia do poder. São Paulo: Ática, 1993.

4. OLIVEIRA, Tito Carlos M. de. (org). Território Sem Limites: Estudos sobre Fronteiras. Campo Grande: Editora UFMS, 2005.

5. Andrei Manoilo. "Revoluciones de los higos", elemento enfurecido o «caos controlado»? // Vida Internacional. Digest. 2011.pp. 148-162

6. Т. П. Петрова Современное состояние внешнеполитических отношений России и Перу: проблемы и перспективы международного сотрудничества // Национацьная безопасность / nota bene.-2012.-3.-C. 86-92.

7. Е.А. Виноградова Стратегическая коммуникация стран ААБА // Национацьная безопасность / nota bene.-2012.-4.-C. 22-28.

8. Т. П. Петрова Аипломатические отношения межАу Россией и Перу: современное состояние и динамика развития // МежАународные отношения.-2012.-1.-С. 46-53.

9. Пашинская В.В. Генезис понятия «Политической коммуникации» // NB: Проблемы общества и политики.-2014.-5.-C. 80-92. DOI: 10.7256/2306-0158.2014.5.12145. URL: http:// www.e-notabene.ru/pr/article 12145.html

10. Аанненберг А.Н. Католическая церковь и «мевый поворот» в $\Lambda$ атинской Америке // МеЖАународные отношения.-2014.-1.-C. 4-10. DOI: 10.7256/2305-560X.2014.1.9559.

11. А. В. ЕвАокимов Эволюция матиноамериканской модели регионализма // Политика и Общество.-2012.-9.-С. 69-73.

12. Е.А. Виноградова Аивия и страны Аатинской Америки: информационное противоборство с Западом // Международные отношения.-2012.-1.-С. 100-105.

13. Хизриева С.С. Информационное обеспечение внешней политики Бразимии в Евросоюзе // Межаународные отношения.-2013.-3.-С. 353-355. DOI: 10.7256/2305-560X.2013. 3.8879.

14. Хизриева С.С. «Мягкая сима» Бразилии в Евросоюзе в периоднахождения увласти Аумы да Симвы. // Тренаы и управмение.-2014.-3.-C. 248-253.DOI: 10.7256/2307-9118.2014.3.12723.

15. Сизоненко А.И. Россия - Бразилия: богатые традиции, хорошее настоящее и перспективное будущее // МежАународные отношения.-2014.-2.-С. 184-188. DOI: 10.7256/2305560X.2014.2.11538.

16. Володенков С.В. Управление современными политическими кампаниями. М.: ИзАательство Московского университета, 2012 г.-312с.

17. Шитова Е.Н. Методы борьбы с коррупцией в Бразимии: достижения и новые вызовы // NB: Межаународные отношения. - 2015. - 1. - C. 123 - 143. DOI: 10.7256/23064226.2015.1.12664. URL: http://www.e-notabene.ru/wi/article_12664.html

18. //. - . . - C. -. URL: 
КОНФАИКТОАОГИЯ • 1(1) • 2014

\section{REFERENCES (TRANSLITERATED)}

1. MARTIN, André. Fronteiras e Nações. São Paulo: Contexto, 1992.

2. NUNES, Marcelino. PARLIM - Parlamento Internacional Municipal, Um Projeto de Integração. Dourados: Editor Nicanor Coelho, 2006.

3. RAFFESTIN, Claude. Por uma geografia do poder. São Paulo: Ática, 1993.

4. OLIVEIRA, Tito Carlos M. de. (org). Território Sem Limites: Estudos sobre Fronteiras. Campo Grande: Editora UFMS, 2005.

5. Andrei Manoilo. "Revoluciones de los higos", elemento enfurecido o «caos controlado»? // Vida Internacional. Digest. 2011. pp. 148-162

6. T. P. Petrova Sovremennoe sostoyanie vneshnepoliticheskikh otnoshenii Rossii i Peru: problemy i perspektivy mezhdunarodnogo sotrudnichestva // Natsional'naya bezopasnost' / nota bene.2012.-3.-C. 86-92.

7. E.A. Vinogradova Strategicheskaya kommunikatsiya stran ALBA // Natsional'naya bezopasnost' / nota bene.-2012.-4.-C. 22-28.

8. T. P. Petrova Diplomaticheskie otnosheniya mezhdu Rossiei i Peru: sovremennoe sostoyanie i dinamika razvitiya // Mezhdunarodnye otnosheniya.-2012.-1.-C. 46-53.

9. Pashinskaya V.V. Genezis ponyatiya «Politicheskoi kommunikatsii»// NB: Problemy obshchestva i politiki.-2014.-5.-C. 80-92. DOI: 10.7256/2306-0158.2014.5.12145. URL: http://www.enotabene.ru/pr/article_12145.html

10. Dannenberg A.N. Kätolicheskaya tserkov' i «levyi povorot»v Latinskoi Amerike // Mezhdunarodnye otnosheniya.-2014.-1.-C. 4-10. DOI: 10.7256/2305-560X.2014.1.9559.

11. L. V. Evdokimov Evolyutsiya latinoamerikanskoi modeli regionalizma // Politika i Obshchestvo.2012.-9.-C. 69-73.

12. E. A. Vinogradova Liviya i strany Latinskoi Ameriki: informatsionnoe protivoborstvo s Zapadom // Mezhdunarodnye otnosheniya.-2012.-1.-C. 100-105.

13. Khizrieva S.S. Informatsionnoe obespechenie vneshnei politiki Brazilii v Evrosoyuze // Mezhdunarodnye otnosheniya.-2013.-3.-C. 353-355. DOI: 10.7256/2305-560X.2013.3.8879.

14. Khizrieva S.S. «Myagkaya sila» Brazilii v Evrosoyuze v period nakhozhdeniya u vlasti Luly da Silvy. // Trendy i upravlenie.-2014.-3.-C. 248-253. DOI: 10.7256/2307-9118.2014.3.12723.

15. Sizonenko A.I. Rossiya - Braziliya: bogatye traditsii, khoroshee nastoyashchee i perspektivnoe budushchee // Mezhdunarodnye otnosheniya.-2014.-2.-C. 184-188. DOI: 10.7256/2305560X.2014.2.11538.

16. Volodenkov S.V. Upravlenie sovremennymi politicheskimi kampaniyami. M.: Izdatel'stvo Moskovskogo universiteta, 2012 g.-312s.

17. Shitova E.N. Metody bor'by s korruptsiei v Brazilii: dostizheniya i novye vyzovy // NB: Mezhdunarodnye otnosheniya. - 2015. - 1. - C. 123 - 143. DOI: 10.7256/23064226.2015.1.12664. URL: http://www.e-notabene.ru/wi/article_12664.html

18. //. - . . - C. - . URL: 